\title{
PEMETAAN KESESUAIAN LAHAN PERUNTUKKAN DAERAH PELABUHAN DENGAN APLIKASI SISTEM INFORMASI GEOGRAFIS DI WILAYAH PESISIR SELATAN KABUPATEN LOMBOK TIMUR
}

\author{
${ }^{1}$ Sukuryadi \\ ${ }^{1}$ Dosen Program Studi Pendidikan Geografi, Universitas Muhammadiyah Mataram \\ Email : Syukur_y80@yahoo.com
}

\begin{abstract}
ABSTRAK
Undang-undang nomor 24 tahun 1992 mengamanatkan bahwa semua kegiatan pembangunan, baik itu dilakukan oleh Pemerintah, Swasta maupun Masyarakat, seyogyanya sesuai dengan Tata Ruang Wilayah yang telah ditetapkan. Selain untuk mencapai efisiensi dan efektivitas pemanfaatan ruang dalam pelaksanaan pembangunan, rencana tata ruang digunakan pula sebagai landasan koordinasi dalam mengurangi konflik ruang dan optimasi pencapaian tujuan. Penyediaan data dan informasi laut yang komprehensif, akurat dan benar, serta dapat ditemukan dengan cepat dan mudah khususunya bagi pembangunan Kelautan Nasional secara umum merupakan hal yang paling mendesak diperlukan. Sehingga kemajuan pembangunan Pusat dan daerah dapat berjalan sinkron dan berkesinambungan. Dalam perkembangannya, wilayah pesisir cenderung berkembang dengan pesat. Namun jika potensi sumberdaya tersebut tidak dikelola dan dimanfaatkan dengan optimal, maka akan berdampak terhadap kerusakan lingkungan, misalnya abrasi pantai, penebangan hutan bakau, rusaknya terumbu karang, serta tercemarnya badan perairan sekitar wilayah pesisir. Penelitian ini bertujuan untuk memetakan tingkat kesesuaian lahan peruntukkan daerah pelabuhan melalui aplikasi Sistem Informasi Geografis (SIG) yang didasari pada hasil survey dan pemetaan di wilayah pesisir selatan Lombok Timur. Hasil penelitian ini diharapkan potensi wilayah pesisir dapat dikembangkan untuk daerah pelabuhan sehingga hasilnya dapat diintegrasikan dengan penelitian sebelumnya sebagai data base perencanaan tata ruang wilayah pesisir bagi pemerintah setempat.
\end{abstract}

Kata Kunci: Pemetaan, Kesesuaian, Pesisir, Pelabuhan

\section{PENDAHULUAN}

Pengelolaan wilayah pesisir harus dilakukan dengan cermat agar manfaat ekonomi dapat diperoleh secara maksimal dan dampak negatif dari pemanfaatannya dapat dikurangi sekecil mungkin. Untuk dapat melakukan pengelolaan sebagaimana dimaksud di atas, maka diperlukan rencana yang memadai. Hal ini dikarenakan bahwa wilayah pesisir merupakan ekosistem yang sangat potensial, namun sangat sensitif pula. Kesalahan dalam pengelolaan dapat menghilangkan potensi manfaat kawasan pesisir, dapat menimbulkan dampak negatif pada wilayah daratan di sekitarnya, dan dapat pula menimbulkan dampak negatif pada wilayah lautan dalam.

Dalam perkembangannya, wilayah pesisir cenderung berkembang dengan pesat. Namun jika potensi sumberdaya tersebut tidak dikelola dan dimanfaatkan dengan seoptimal mungkin, maka akan berdampak terhadap kerusakan lingkungan, misalnya abrasi (pengikisan) garis pantai, penebangan hutan bakau, rusaknya terumbu karang, serta tercemarnya badan perairan sekitar wilayah pesisir. Kerusakan lingkungan tersebut pada gilirannya dapat menurunkan produktivitas perairan (populasi perikanan) di wilayah pesisir sehingga dapat mempengaruhi daya tarik Paedagoria, September 2016, ISSN 2086-6356 pariwisata, khusunya wisata bahari yang dapat berdampak pada penurunan tingkat kesejahteraan masyarakat pesisir.

Munculnya berbagai dampak negatif seperti di atas antara lain disebabkan oleh fungsi ekologis dan fungsi ekonomi wilayah pesisir tidak ditempatkan secara proporsional dalam mempertimbangkan pembangunan dan pemanfaatan lahan wilayah pesisir. Oleh karena itu, untuk tidak memperbesar dampak negatif yang timbul, sejak sekarang perlu ditempuh berbagai langkah yang berorientasi pada pemanfaatan lahan dan sumberdaya pesisir yang bernilai tambah tinggi, tetapi disertai dengan pelestarian fungsi ekologisnya (keseimbangan ekosistem wilayah pesisir).

Untuk itu maka pengelolaan wilayah pesisir dan pantai perlu dikembangkan perencanaan pengelolaan wilayah pesisir sebagai langkah dalam pencapaian hasil yang optimal. Tujuannya dalah untuk mengoptimalkan keuntungan-keuntungan yang disediakan oleh kawasan pesisir dan untuk meminimalkan konflik serta berbagai perusakan yang dilakukan oleh manusia di dalam wilayah pesisir. Guna mewujudkan hal tersebut, penataan ruang berupa penetapan fungsi zonasi diharapkan dapat menjaga keseimbangan antara perlindungan ekosistem dan eksploitasinya dalam pengelolaan wilayah pesisir dan lautan. Zonasi 
merupakan upaya penetapan batas-batas fungsional suatu peruntukan sesuai dengan potensi sumberdaya, daya dukung dan proses-proses ekologi yang berlangsung dalam sistem tersebut.

Dengan demikian maka sangat diperlukan kegiatan penelitian ini dilakukan dengan tujuan untuk memetakan potensi kesesuaian wilayah pesisir selatan Lombok Timur sebagai wilayah pelabuhan yang nantinya dapat dijadikan sebagai arahan pemanfaatan ruang di kawasan pesisir dan lautan Kabupaten Lombok Timur bagian Selatan.

\section{METODE PENELITIAN \\ A. Alat dan Bahan}

Tabel 1. Alat-alat yang digunakan dalam pengambilan data lapangan.

\begin{tabular}{clcl}
\hline No. & \multicolumn{1}{c}{ Nama Alat } & Jumlah & \multicolumn{1}{c}{ Kegunaan } \\
\hline 1. & $\begin{array}{l}\text { Global Positioning System } \\
\text { (GPS) }\end{array}$ & 1 buah & Penentu posisi stasiun pengamatan \\
2. & Kapal & I buah & Alat transportasi \\
3. & Layang-layang arus & 1 buah & Pengukur arus pantai \\
4. & Rambu ukur/tiang skala & 1 buah & Pengukur ombak dan pasut \\
5. & Tali pengukur ke dalaman & 1 buah & Pengukur ke dalaman \\
6. & Kompas Geologi & 1 buah & Penentu arah \\
7. & Stopwatch & 1 buah & Penentu/menghitung waktu \\
8. & Alat Selam Dasar & 1 set & Pengamatan Secara Visual \\
9. & Kamera Foto Digital & 1 buah & Dokumentasi proses \\
10. & Alat tulis menulis & - & Pencatatan hasil pengukuran \\
11. & Handrefactometer & 1 buah & Mengukur salinitas \\
12. Software pengolah data (MS & 1 buah & Mengolah data \\
13. Software analisa data GIS & 1 buah & Mengolah data \\
\hline
\end{tabular}

Sedangkan sebagai bahan yang digunakan antara lain : Peta Rupa Bumi skala $1: 50.000$

\section{B. Prosedur Penelitian}

1. Observasi lapangan dan penentuan objek penelitian

Observasi lapangan dilakukan untuk memperoleh gambaran kondisi umum wilayah penelitian (Gambar 1). Selanjutnya dapat ditentukan tentang kriteria-kriteria yang akan dijadikan dasar dari penelitian ini.

\section{Pengumpulan data}

\section{a. Pengukuran Arah dan Kecepatan Arus}

Pengukuran kecepatan arus dilakukan dengan menggunakan layang-layang arus dan stop watch, sedangkan arah arus ditentukan dengan menggunakan kompas geologi pada arah pergerakan layang-layang arus. Kecepatan arus diperoleh dengan menggunakan persamaan berikut:

dimana :

$$
v=\frac{s}{t}
$$

$$
\begin{array}{ll}
v & =\text { kecepatan arus (m/detik) } \\
s & =\text { jarak/panjang tali (meter) }
\end{array}
$$

$t \quad=$ waktu yang ditempuh (detik)

\section{b. Pengukuran kedalaman}

Pengukuran kedalaman menggunakan batu duga yang ditenggelamkan hingga menyentuh dasar perairan.

c. Pengukuran Salinitas

Pengukuran salinitas dilakukan dengan menggunakan handrefractometer.

d. Pengukuran Arah dan Tinggi Gelombang

Penentuan data gelombang yang terdiri dari tinggi gelombang signifikan $(\mathrm{H} 1 / 3)$, perode gelombang $(\mathrm{T})$, dan periode gelombang signifikan (T1/3) (Pratiko, 1996 dalam Saleng, 2000) yang selengkapnya di hitung dengan rumus sebagai berikut :

Keterangan :

$$
H_{\frac{1}{3}}=\frac{1}{3} \sum_{N}^{N-1}\left[H_{1}+H_{2}+\cdots+H_{N}\right]
$$

$H_{\frac{1}{3}}$ : Tinggi gelombang signifikan $(m)$ 
$N: \frac{1}{3}$ jumlah gelombang terukur

\section{e. Pengukuran Pasang surut}

Pengukuran Pasang Surut dilakukan selama 15 hari untuk masing-masing lokasi penelitian. Pengambilan Data pasang surut dilakukan dengan tujuan untuk mengetahui tunggang pasang surut (A) dan pasang tertinggi dan terendah dalam sebulan.

\section{Analisa Data}

Penelitian selanjutnya melakukan analisa data dengan SIG yang berbasis pada analisis data spasial dan deskriptif/tabular yang bertujuan untuk menentukan potensi lahan untuk pengelolaan sumberdaya pesisir/laut. Data-data (hasil survei dan data sekunder) ini selanjutnya akan di analisis dalam software GIS, analisis dilakukan dengan memasukkan data survei dalam peta dasar melalui sistem overlay data pada setiap peubah/kriteria dengan mempertimbangkan pembobotan dan skala penilaian untuk mendapatkan nilai skoring dalam menentukan kesesuaian lahan yang akan menghasilkan suatu peta kesesuaian dan prospektif pengelolaan sumberdaya pesisir/laut.

Kriteria kesesuaian dapat dikelompokkan ke dalam beberapa aspek, kriteria teknis yang menyangkut kesesuaian dilihat dari aspek fisik yang meliputi beberapa aktivitas utama pada kawasan pesisir yaitu sebagai wilayah pelabuhan.

Tabel 2. Matriks Kesesuaian Untuk Pelabuhan

\begin{tabular}{ccccc}
\hline \multirow{2}{*}{ Faktor } & \multirow{2}{*}{ Simbol } & \multicolumn{3}{c}{ KELAS KESESUAIAN LAHAN } \\
\cline { 2 - 5 } & & $\mathrm{S} 1$ & $\mathrm{~S} 2$ & $\mathrm{~N}$ \\
\hline Kedalaman & $\mathrm{D}(\mathrm{m})$ & $\mathrm{D}>5,5$ & $\mathrm{D}<5,5$ \\
\hline $\begin{array}{c}\text { Kisaran } \\
\text { Pasang Surut }\end{array}$ & $\mathrm{A}(\mathrm{m})$ & $\mathrm{A}<2$ & $2<\mathrm{A}<4$ & $\mathrm{~A}>4$ \\
\hline $\begin{array}{c}\text { Kisaran Arus } \\
\text { Laut }\end{array}$ & $\mathrm{V}(\mathrm{m} / \mathrm{s})$ & $\mathrm{V}<0,5$ & $0,5<\mathrm{V}<1$ & $\mathrm{~V}>1$ \\
\hline Tinggi Ombak & $\mathrm{H}(\mathrm{m})$ & $\mathrm{H}<0,2$ & $0,2<\mathrm{H}<1,2$ & $\mathrm{H}>1,2$ \\
\hline Luas areal & $\mathrm{L}(\mathrm{m} 2)$ & $\mathrm{L}<126.000$ & & $\mathrm{~L}<40.000$ \\
\hline adjantji (2001) & & & &
\end{tabular}

4. Tahapan Kerja Untuk Pemetaan Kesesuaian Lahan

a. Tabulasi data

Data hasil analisis laboratorium berupa data fisika dan kimia oseanografi dikumpulkan menjadi satu data base yang lengkap. Hal ini dilakukan untuk memudahkan proses simulasi data pada komputer.

b. Verifikasi data

Verifikasi data dilakukan untuk memeriksa kebenaran dan keakuratan data pada tables yang telah ditabulasi. Data yang memiliki standar baku tidak normal dari kondisi sebenarnya, dapat dilakukan perubahan atau pengecekan ulang kembali.

c. Interpolasi data

Menginterpolasi data hasil analisis kondisi fisika dan kimia oseanografi pada suatu bidang datar yang bergeoreferensi titik-titik ordinat di bumi. Masing-masing variabel kriteria kesesuaian lahan dilakukan interpolasi untuk membentuk peta tematik tersendiri tiaptiap parameter dan pemanfaatan lahan.

d. Pemodelan

Pemodelan dengan memanfaatkan software Sisten Informasi Geografis, merupakan salah satu cara untuk meletakkan perencanaan dan kajian analisis yang tepat untuk menggambarkan karakteristik dan potensi suatu wilayah. Model yang dilakukan adalah suatu konstruksi simulasi fisik dari dunia nyata. Pemodelan ini meliputi Overlay kriteria kesesuaian lahan, yang berupa layerlayer peta tematik. Layer-layer peta ini terdiri dari kodisi fisika dan kimia oseanografi berdasarkan matriks kesesuaian lahan. Overlay ini dilakukan dengan cara perbandingan secara teliti pada setiap layerlayer peta, untuk menentukan tingkat kesesuaian wilayah pesisir.

e. Analisis Penentuan Tingkat Kesesuain Lahan

Analisis penentuan tingkat kesesuaian lahan pesisir yang mengacu pada tabel Matriks kesesuaian lahan yang berupa data kimia dan fisika oseanografi. Identifikasi lahan yang memiliki potensi kesesuaian rendah, sedang, tinggi dengan pertimbangkan skill adjustment (keahlian dan keprofesionalan) dari masing-masing pemanfaatan.

Analisis dari setiap layer peta tematik kriteria kesesuaian lahan, selanjutnya dikombinasi dengan metode Overlay untuk memperoleh peta Potensi Pengelolaan Wilyah Pesisir, maka didapatkan Informasi lengkap mengenai wilayah yang memiliki tingkat kesesuaian lahan untuk pengelolaan/pemanfaatan yang lebih baik. 

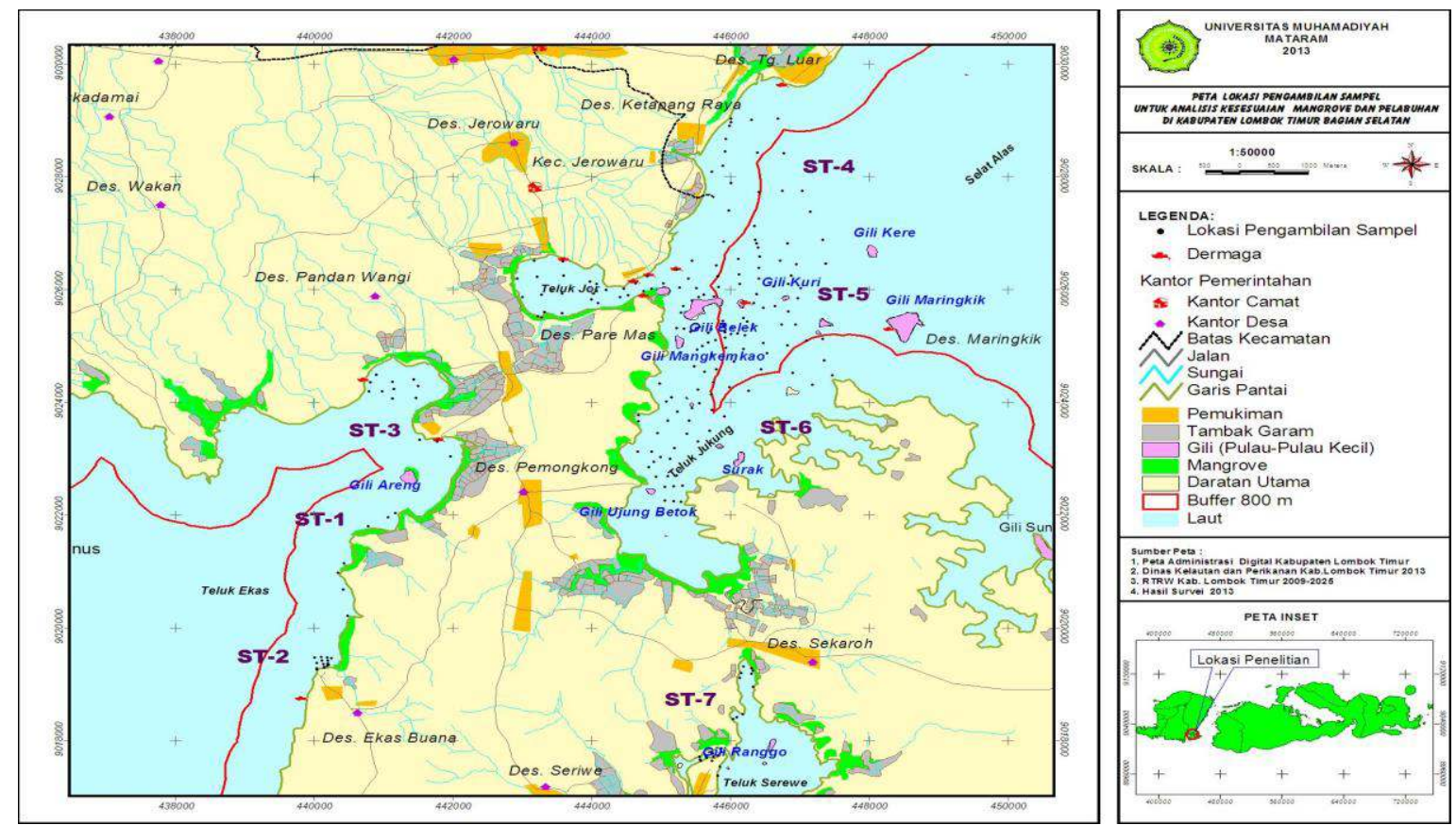

Gambar 1. Peta Lokasi Penelitian

\section{HASIL DAN PEMBAHASAN}

A. Analisis Kondisi Parameter Fisik untuk Pengembangan Pelabuhan di Pesisir Selatan Kabupaten Lombok Timur (Teluk Ekas, Teluk Serewe,Teluk Jor dan Teluk Jukung)

Pelabuhan Perikanan adalah tempat yang terdiri dari daratan dan perairan di sekitarnya dengan batasbatas tertentu sebagai tempat kegiatan pemerintahan dan kegiatan ekonomi yang dipergunakan sebagai tempat kapal bersandar, berlabuh, naik turun penumpang dan / atau bongkar muat barang yang dilengkapi dengan fasilitas keselamatan pelayaran dan kegiatan penunjang. Landasan hukum dari Pelabuhan Perikanan terdapat pada Peraturan Menteri Perikanan dan Kelautan Nomor Per.16/MEN/2006 tentang Pelabuhan Perikanan bahwa: Sesuai dengan Pasal 41 Undang-Undang Nomor 31 Tahun 2004 tentang Perikanan, Pelabuhan Perikanan mempunyai peranan penting dalam mendukung peningkatan produksi perikanan, memperlancar arus lalu lintas kapal perikanan, mendorong pertumbuhan perekonomian masyarakat perikanan, pelaksanaan dan pengendalian sumberdaya ikan, serta mempercepat layanan terhadap kegiatan di bidang usaha perikanan.

Pembangunan Pelabuhan Perikanan dirancang sesuai dengan kemampuan sumberdaya wilayah, termasuk sumberdaya kelautan, serta sesuai dengan volume usaha perikanan di wilayah pengembangan perikanan yang telah ditetapkan. Pelabuhan Perikanan dibagi menjadi 4 golongan, yaitu Pelabuhan Perikanan Samudera (PPS) atau tipe A, Pelabuhan Perikanan Nusantara (PPN) atau tipe B, Pelabuhan Perikanan Pantai (PPP) atau tipe C, dan Pangkalan Pendaratan Ikan (PPI) atau tipe D.

Adapun kondisi factor-faktor lingkungan yang berkaitan secara langsung berupa parameter fisika yang mendukung untuk pengembangan pelabuhan antara lain sebagaimana disajikan pada Tabel 2:

Tabel 2. Data Hasil Pengukuran Parameter Oceanografi untuk analisis Kesesuaian lahan Pelabuhan/Dermaga Perikanan

\begin{tabular}{|c|c|c|c|c|c|}
\hline \multirow{2}{*}{ No } & \multirow{2}{*}{ Parameter } & \multirow{2}{*}{$\begin{array}{l}\text { Simbol } \\
\text { (Satuan) }\end{array}$} & \multicolumn{3}{|c|}{ Nilai } \\
\hline & & & Ekas & Jor/Jukung & Seriwe \\
\hline 1 & Kedalaman & $\mathrm{D}(\mathrm{m})$ & $0,5-8,59$ & $0,5-13,99$ & $0,5-32$ \\
\hline 2 & $\begin{array}{l}\text { Kisaran Pasang } \\
\text { Surut }\end{array}$ & $A(m)$ & $2,6-2,9$ & $1,8-2,6$ & $1,5-1,8$ \\
\hline
\end{tabular}




\begin{tabular}{|c|c|c|c|c|c|}
\hline 3 & $\begin{array}{l}\text { Kisaran } \\
\text { Laut }\end{array}$ & $\mathrm{V}(\mathrm{m} / \mathrm{s})$ & $0,03-0,09$ & $0,03-0,33$ & $0,03-0,33$ \\
\hline 4 & Tinggi Ombak & $\mathrm{H}(\mathrm{m})$ & $0,10-0,12$ & $0,10-20$ & $0,10-0,16$ \\
\hline
\end{tabular}

\section{Kedalaman}

Berdasarkan hasil pengukuran di tiga lokasi perairan teluk yakni di Teluk Ekas menujukkan kondisi kedalaman berada pada kisaran 0,50 3,2 meter yang berarti dikategorikan tidak sesuai $(\mathrm{N}), 3,2-5,9 \mathrm{~m}$ yang dikategorikan sesuai (S2) dan 5,9 - 8,59 $\mathrm{m}$ dikategorikan sangat sesuai (S1), keberadaan wilayah perairan yang tidak sesuai tersebut dikarenakan wilayah tersebut terlalu dangkal terlebih pada saat surut air laut terjadi di perairan Teluk Ekas seperti lapangan yang kering, sehingga cukup menyulitkan bagi kapal-kapal besar untuk bersandar ke pinggir pantai. Untuk pelabuhan sendiri pembangunannya akan jauh ke tengah untuk mendapatkan kedalaman yang ideal bagi kapal yang agak besar, demikian halnya dengan Teluk Serewe dengan kondisi kedalaman berada pada kisaran 0,5-3,2 meter menunjukkan kategori tidak sesuai karena lokasi kajian yang relative berada pada daerah yang dangkal sedangkan untuk Teluk Jor (Kawasan Teluk Jukung) kondisi kedalaman berada pada kisaran $0,50-3,2$ meter yang berarti dikategorikan tidak sesuai $(\mathrm{N}), 3,2-5,9 \mathrm{~m}$ yang dikategorikan sesuai (S2) dan 5,9-8,59 m dikategorikan sangat sesuai (S1).

Menurut Mappadjantji, A,. (2001), bahwa syarat utama dalam memilih suatu daerah pantai peruntukan pelabuhan adalah kedalamannya. Pada dasarnya kedalaman dari dasar kolam pelabuhan ditetapkan berdasarkan sarat maksimum kapal yang akan bertambat dengan jarak aman sebesar 0,8 - 1,0 meter di bawah lunas kapal. Kedalaman minimal yang dibutuhkan bagi suatu pelabuhan adalah 5 meter dan yang ideal adalah 12 meter. Kedalaman yang dimaksud adalah jarak antara permukaan air laut dengan dasar laut pada saat surut maksimum.

\section{Tunggang pasang (A)}

Pasang surut adalah fluktuasi muka air laut sebagai fungsi waktu karena adanya gaya tarik benda-benda di langit terutama matahari dan bulan terhadap massa air laut di bumi. Pengetahuan tentang pasang surut adalah penting dalam perencanaan pelabuhan, elevasi muka air tertinggi ( pasang ) sangat penting dalam menentukan elevasi puncak bangunan pantai dan fasilitas pelabuhan.sermentara kedalaman alur pelayaran / pelabuhan ditentukan oleh muka air surut.

Mengingat elevasi muka air laut selalu berubah setiap saat, maka diperlukan suatu elevasi yang ditetapkan berdasarkan data pasang surut, yang dapat digunakan sebagai pedoman di dalam perencanaan suatu pelabuhan. Beberapa elevasi tersebut adalah sebagai berikut :

1. Muka air tinggi (high water level), muka air tertinggi yang dicapai pada saat air pasang dalam satu siklus pasang surut.

2. Muka air rendah (low water level), kedudukan air terendah yang dicapai pada saat air surut dalam satu siklus pasang surut.

3. Muka air tinggi rerata (mean high water level, $\mathrm{MHWL}$ ), adalah rerata dari muka air tinggi selama periode 19 tahun.

4. Muka air rendah rerata (mean low water level, MLWL), adalah rerata dari muka air rendah selama periode 19 tahun.

5. Muka air laut rerata (mean sea level, MSL), adalah muka air rerata antara muka air tinggi rerata dan muka air rendah rerata.

6. Muka air tinggi tertinggi (highest high water level, $\mathrm{HHWL}$ ), adalah air tertinggi pada saat pasang surut purnama atau bulan mati.

7. Air rendah terendah (lowest low water level, LLWL), adalah air terendah pada saat pasang surut purnama atau bulan mati.

8. Higher high water level, adalah air tertinggi dari dua air tinggi dalam satu hari, seperti dalam pasang surut tipe campuran.

9. Lower low water level, adalah air terendah dari dua air rendah dalam satu hari.

Berdasarkan data yang ada bahwa kondisi pasang surut di Teluk Ekas berada pada kisaran 2,6 - 2,9 meter yang berarti termasuk dalam kategori sesuai (S2), sedangkan untuk Teluk Jor dan Kecibing ( Kawasan Teluk Jukung) kisaran pasang surutnya berada kisaran 2,1 - 2,6 meter dengan kategori sesuai (S2) dan kisaran pasang surut untuk Teluk Serewe berada pada kisaran 1,5 - 1,8 meter yang berarti termasuk dalam kategori sangat sesuai (S1).

Ketiga lokasi perairan tersebut memiliki tipe pasang surut yakni tipe semidiurnal dimana terjadi dua kali pasang dan surut dalam sehari. Mappadjantji, A,. (2001), parameter pasang surut yang ideal bagi peruntukan pelabuhan adalah lebih kecil dari 2 meter atau tidak lebih besar dari 5 meter. Kondisi tersebut mutlak dibutuhkan mengingat kawasan geografis kawasan pantai Indonesia, terutama kemudahan navigasi untuk kapal-kapal yang akan berlabuh dan perencanaan konstruksi bangunan maritimnya. 


\section{Kecepatan Arus (V)}

Berdasarkan hasil pengukuran di lapangan bahwa di Teluk Ekas menujukkan kondisi arus pantai berada pada kisaran $0,03-0,09 \mathrm{~m} /$ detik sehingga untuk pengembangan pelabuhan dikategori sangat sesuai (S1) dan untuk peraian Teluk Jor dan Kecibing kisaran arusnya yakni 0,15 - 0,33 $\mathrm{m} /$ detik sehingga dikategorikan sangat sesuai (S1). Demikian juga dengan Teluk Serewe dengan kisaran kecepatan arus laut yakni 0,21 $0,27 \mathrm{~m} /$ detik yang menunjukkan kategori sangat sesuai (S1) untuk pengembangan pelabuhan. Mappadjantji (2001) menyatakan bahwa pengetahuan tentang arus laut dalam penentuan kawasan pelabuhan mutlak dibutuhkan. Kecepatan arus ini sangat mempengaruhi maneuver keluar masuk kapal. Kecepatan arus laut yang ideal bagi suatu pelabuhan adalah lebih kecil dari 0,5 $\mathrm{m} /$ detik atau tidak lebih besar dari 1 $\mathrm{m} /$ detik, jika kecepatan laut lebih besar dari 1,0 $\mathrm{m} /$ detik, maka memerlukan bangunan pengaman pantai.

\section{Tinggi Gelombang (H1/3)}

Secara umum gelombang laut ditimbulkan oleh angin meskipun gelombang dapat ditimbulkan oleh berbagai sebab, misalnya letusan gunung berapi di dasar laut, tsunami, gerakan kapal dan lain sebagainya. Gelombng digunakan untuk merencanakan bangunan pemecah gelombang dan bangunan pelabuhan lainnya. Bentuk gelombang di air yang disebabkan oleh angin biasanya terdiri dari gelombang dengan bermacam tinggi dan periode serta arah perambatan. Dengan kata lain, gelombang laut yang dibangkitkan oleh angin bersifat acak. Parameter untuk menjelaskan gelombang diantaranya adalah tinggi, panjang gelombang dan kedalaman air tempat terjadinya gelombang

Gelombang laut merupakan reaksi permukaan air laut oleh seretan angin, sehingga arah angin di laut identik dengan arah gelombang. Gelombang harus diperhitungakan dalam setiap aktivitas di pesisir dan laut. Besar dan arah gelombang berpengaruh terhadap proses dinamika pantai, daya tahan struktur bangunan di pesisir, kehidupan biota dan pelayaran.

Berdasarkan hasil pengukuran di semua lokasi penelitian menunjukkan bahwa pengamatan tersebut dikategorikan sangat sesuai dengan kisaran tinggi gelombang $0,10-0,20$ meter. Kondisi ini cukup baik dalam aktivitas kepelabuhanan karena pengaruh gelombang yang kecil akan memudahkan dalam proses bongkar muat. Selain itu, tinggi gelombang pada kondisi ini dapat memperlambat proses sedimentasi atau erosi pantai pada tipe pantai berpasir (Dahuri et.al, 2004)

Berdasarkan hasil pengukuran di tiga wilayah teluk yakni di Teluk Ekas menujukkan kondisi tinggi gelombang berada pada kisaran 0,10 0,12 meter sehingga untuk pengembangan pelabuhan tinggi gelombang tersebut dikategorikan sangat sesuai (S1), demikian halnya dengan Teluk Serewe dengan kondisi tinggi ombak berada pada kisaran 0,10 - 0,16 meter yang juga menunjukkan kategori sangat sesuai (S1) dan untuk Teluk Jor dan Kecibing (Kawasan Teluk Jukung) kondisi tinggi ombak berada pada kisaran $0,10-0,20$ meter dengan kategori sangat sesuai (S1).

Menurut Mappadjantji (2001) bahwa secara umum dapat dikatakan tinggi gelombang ideal untuk suatu pelabuhan adalah maksimum 0,2 meter atau tidak lebih dari 1,2 meter.

\section{B. Evalusi Kesesuaian Lahan untuk Pelabuhan}

Berdasarkan hasil analisis spasial untuk
menentukan tingkat kesesuain lahan untuk pengembangan pelabuhan yang terdapat wilayah pesisir Selatan Kabupaten Lombok Timur yang tersebar di wilayah perairan Teluk Ekas, Serewe, dan Teluk Jor dan Kecibing (Kawasan Teluk Jukung) dengan melakukan buffer garis pantai sejauh $800 \mathrm{~m}$ didapatkan bahwa distribusi luasan untuk kelas kesesuain lahan dengan kategori sangat sesuai (S1) dari wilayah cakupan penelitian yakni sekitar 637,528 ha, dan untuk kelas kesesuain lahan dengan kategori sesuai (S2) sekitar 1923,065 ha. Adapun gambaran potensi hasil analisis kesesuain lahan di empat wilayah perairan untuk pengembangan pelabuhan sebagaimana terlihat pada Gambar 2 berikut: 


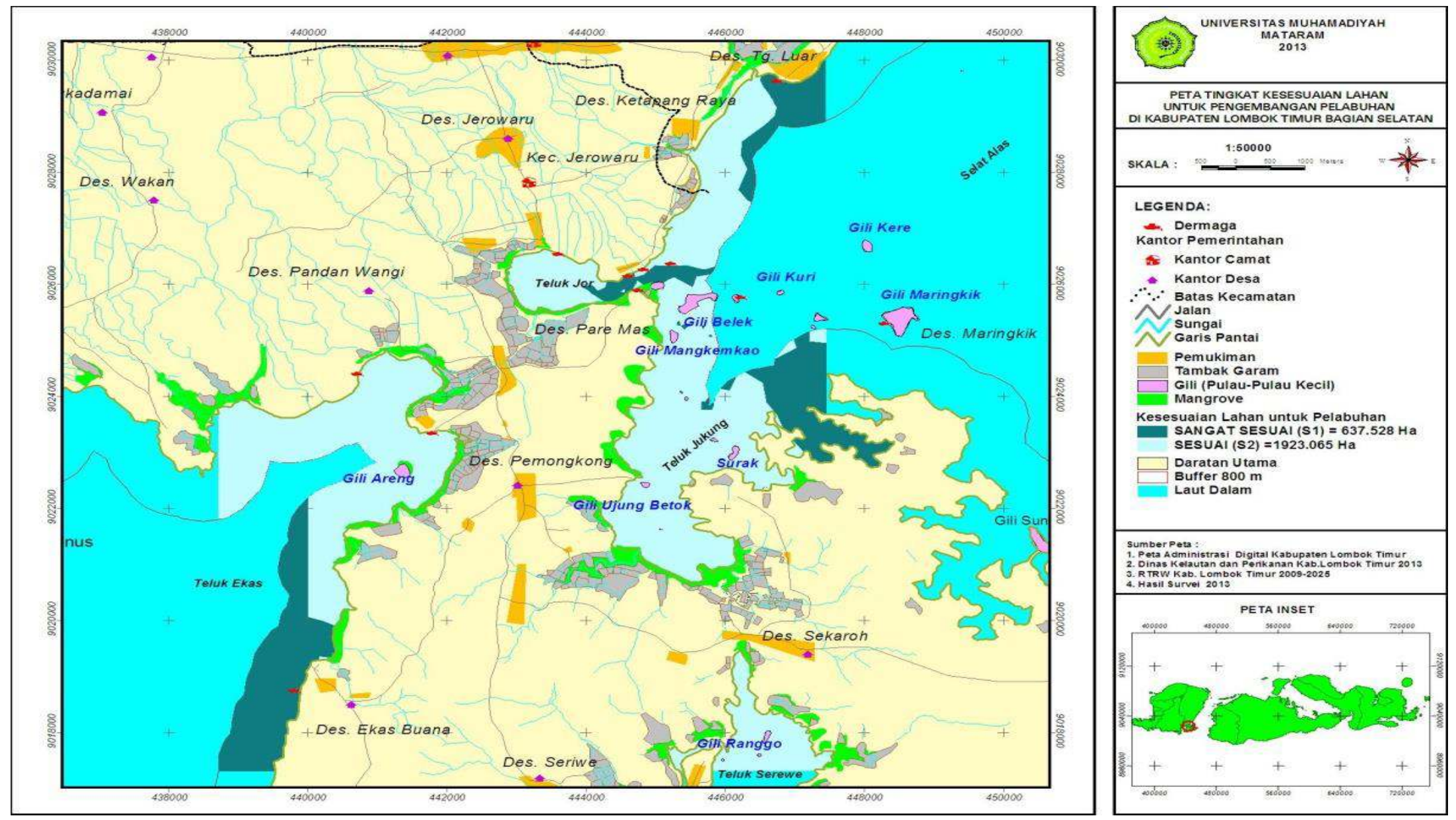

Gambar 2. Peta Tingkat Kesesuaian Lahan untuk Pelabuhan di Wilayah Pesisir Selatan Kabupaten Lombok Timur

\section{PENUTUP}

A. Simpulan

1. Potensi kesesuaian wilayah pesisir selatan Lombok Timur untuk lahan pembangunan/pengembangan pelabuhan perikanan/dermaga memiliki tingkat kesesuaian yang berbeda-beda sesuai dengan karakteristik parameter lingkungannya.

2. Tingkat kesesuaian Lahan untuk pelabuhan/dermaga perikanan terdiri dari 2 kategori yaitu Sangat Sesuai (S1), dan Sesuai (S2) dengan distribusi luasan untuk kelas kesesuain lahan dengan kategori sangat sesuai 
3. wilayah cakupan penelitian yakni sekitar 637,528 ha, dan untuk kelas kesesuain lahan dengan kategori sesuai (S2) sekitar 1923,065 ha

\section{B. saran}

1. Untuk meningkatkan nilai penting dari suatu lahan pesisir sebaiknya dalam pemanfaatan dan pengembangannya harus memperhatikan faktorfaktor lingkungan yang menjadi daya dukungnya (carring capacity).

2. Perlunya perhatian khusus terkait faktor penentu keberhasilan pengembangan dan pemanfaatan potensi lahan seperti bentang alam (landscape) serta parameter yang lain seperti karakteristik oceanografi dan substrat dasar perairan sehingga membantu dalam perencanaan peruntukan kawasan mangrove dan pelabuhan sehingga nantinya dapat dikembangkan demi kebutuhan dan kesejateraan masyarakat pesisir sekitarnya,

3. Pemerintah setempat harus memiliki acuan yang jelas dalam menentukan rencana penggunaan lahan wilayah pesisir supaya potensi yang ada termanfaatkan secara optimal demi kesejahteraan masyarakat serta mengurangi konflik kepentingan antar masyarakat,

4. Pemerintah setempat bersama pemerintah pusat harus menindaklanjuti rencana tata ruang wilayah pesisir selatan Lombok Timur sesuai peruntukkannya sehingga dapat meningkatkan pendapatan asli daerah yang berasal dari pemberdayaan wilayah pesisir dan lautan secara terpadu.

5. Hendaknya pemerintah daerah mendukung program pusat dengan berbasis pada masyarakat pesisir supaya program kelautan dan perikanan berjalan sesuai dengan target yang telah ditetapkan pada masing-masing program.

\section{DAFTAR PUSTAKA}

Dahuri, R. J. Rais,. S.P. Ginting dan M.J. Sitepu. 1996. Pengelolaan Sumberdaya Wilayah Pesisir dan Lautan Secara Terpadu. PT. Pradya Paramita. Jakarta.

Dahuri, R., J. Rais, S.P.Ginting, dan M.J.Sitepu., 2004, Pengelolaan Sumberdaya Wilayah Pesisir dan Lautan Secara Terpadu (Edisi Revisi), PT. Pradnya Pratama, Jakarta.

Mappadjantji A., Andi. 2001. Penataan Ruang Wilayah Pesisir. Pustaka Ramadhan. Bandung.

Nontji, A., 1987. Laut Nusantara. Penerbit Djambatan. Jakarta.

Nybakken, J.W., 1992. Biologi Laut. Suatu Pendekatan Ekologis. Gramedia. Jakarta.

Sugiarto, A. 1986. Peranan Ekosisitem Hutan Bakau Khususnya di Tinjau dari Pembangunan Perikanan. Prosiding Pertemuan Teknis Evaluasi Hasil Survey Hutan bakau, Jakarta.
Suriamihardja, D.A, Sakka dan A. Massinai. 1998. Studi of Siwa Oceanographic Condition. Collaborative Enviromental Project in Indonesia University Consortium on The Environment. Center for Environmental Study. Hasanuddin University. Makassar. 